\title{
The lack of refugee burden-sharing in Tanzania: tragic effects
}

\author{
Michèle Morel \\ Department of International Public Law, Ghent University, Belgium
}

\begin{abstract}
The United Republic of Tanzania has been and currently still is one of the most important host countries in the world for refugees. The majority of those refugees have been living in camps for many years and have no prospect of a durable solution of their situation via repatriation, integration or resettlement. As a result, Tanzania is confronted with protracted refugee situations. The purpose of this article is to answer the question who is responsible for the plight of these refugees. Tanzania's national refugee policy since the I96os is analysed, whereby a clear evolution can be observed from an 'Open Door' policy to a policy with heavy restrictions and the absence of local integration as a durable solution. However, it will be concluded that it is not Tanzania but the international community that is to be held responsible. There is a lack of international refugee burden-sharing, as evidenced by the lack of an international legal framework for durable solutions for refugees. A 'common but differentiated responsibility' should be the basis of international cooperation to solve protracted refugee situations such as those occurring in Tanzania.
\end{abstract}

Key words: African Great Lakes region, protracted refugee situations, national policy

\section{Introduction}

The majority of today's refugees around the globe subsist in a state of limbo. They have lived in exile for far too long, and often survive confined to camps (UNHCR, 2006: I05). Although the concept of protracted refugee situations has never been formally defined by the United Nations High Commissioner for Refugees (UNHCR), refugees can be regarded as being in such a situation when, having lived in exile for more than five years (Crisp, 2003: $\mathrm{I}$ ), they still have no immediate prospect of finding a durable solution...by means of voluntary repatriation, local integration, or resettlement (Crisp, 2003: I). At the end of 2007, Tanzania was hosting about 436,00o refugees, mainly from Burundi and DR Congo, with a majority finding themselves in protracted refugee situations (UNHCR, 2006: 107; UNHCR, 2008: 8). For the purpose of this article, it is argued that 'refugees' should not be understood as only those persons defined in the 195I Convention relating to the Status of Refugees ('I95I Convention'), i.e. persecution-related refugees; the term refers to all those who are included as 'refugees' in the statistics of the UNHCR as shown in figure I below. These are: individuals recognised under the I95I Convention and its 1967 Protocol; the I 969 OAU Convention Governing the Specific Aspects of Refugee Problems in 
Africa ('r969 OAU Convention'); those recognised in accordance with the UNHCR Statute; individuals granted complementary forms of protection; or, those enjoying 'temporary protection'. Conflict-related displacement is thus, amongst others, also included.

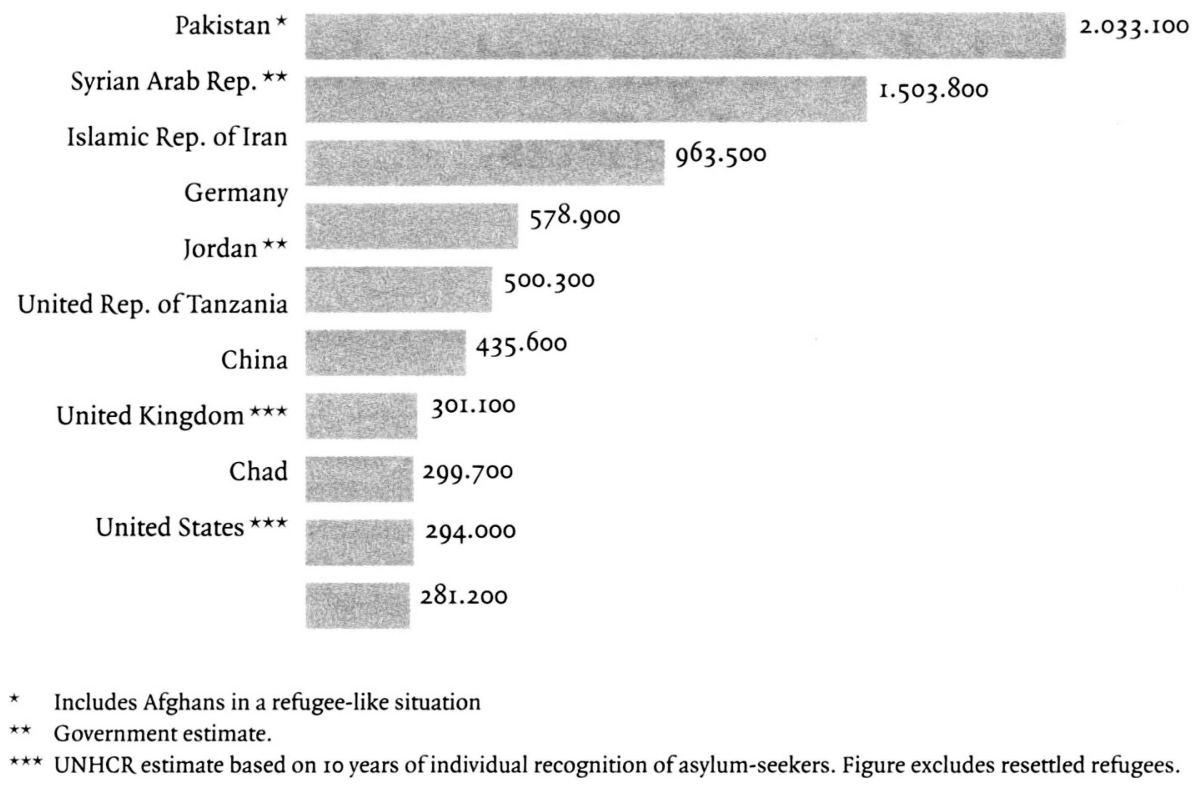

Figure 1: Major refugee hosting countries, end-2007 (Source: UNHCR, 2008:8).

The question arises: what are the causes of these protracted refugee situations in Tanzania and who is responsible for them? It is the intention of this paper to analyse the role of national and international actors in long-term refugee situations. It will be argued that, rather than holding Tanzania accountable, the international community has the urgent task of assuming responsibility. Nevertheless, in the meantime Tanzania should take an approach that presents a middle course between durable solutions and mere isolated encampment.

This paper focuses especially on protracted refugee situations in northwestern Tanzania. It will examine the relation between those refugee situations and more durable solutions, as well as evaluate the evolution of Tanzania's policy towards refugees in the light of that relation. As the most important refugee-hosting country on the African continent with refugees coming from different areas in the Great Lakes region and as the 'African country of solidarity and generosity' - Tanzania was an advocate of the abovementioned 1969 OAU Convention - Tanzania is one of the best examples of how the lack of international responsibility may gravely affect a national policy. 


\section{The link between protracted refugee situations and durable solutions}

Causes of protracted refugee situations

One can argue that a number of different, but interrelated factors contain the answer to the question why so many refugees have no immediate prospect of a solution to their plight (Crisp, 2003: 2-6). The latter author commences his list with the elements of conflict and non-intervention. Armed conflicts, which originally forced people to flee, have dragged on for many years, making it impossible for them to return to their homeland (Crisp, 2003: 3). It is clear that due to and during long-lasting armed conflicts, voluntary repatriation as durable solution is not possible. Moreover, the fighting often has been and still is sustained by the fact that various actors have a vested economic interest in the continuation of armed conflict (Crisp, 2003: 3). In addition, the international community often fails to bring armed conflicts to an end. This is especially true in Africa, where the 'geopolitical and economic stakes' (Crisp, 2003: 3) for industrialized states have generally been low.

Another cause of protracted refugee situations is the shift, from the mid-I980s onwards, from integration in another country - local integration or resettlement - to (in?) voluntary repatriation as the internationally preferred durable solution (Crisp, 2003: 3). This cause is strongly related with the first factor: if there is no peace, then voluntary repatriation is not possible.

The 'residual caseloads' and the notion of 'political hostages' are also telling factors as to why refugees find themselves in protracted refugee situations. 'Residual caseloads' are refugees who, although other members of the same population have found a durable solution, decide to remain in exile, and this for many different reasons (Crisp, 2003: 4-5). On the theme of 'political hostages' Crisp (2003: 4-5) writes that political, military and economic interests of key actors complicate the search for durable solutions; e.g. the location of refugee camps may be selected on the basis of political and military, rather than humanitarian reasons.

Some literature on this topic does not discriminate between the various causes of protracted refugee situations, but only emphasises 'political impasses' as the crucial explanatory factor (UNHCR, 2005: I50-I5I; UNHCR, 2006: I09 and II2). Long-term refugee situations are, according to this view, the result of political action and inaction, both in the country of origin (the persecution or violence that led to the flight) and in the country of asylum (UNHCR, 2005: 150-15I) - the latter through the lack of or harsh policy responses to refugee inflows. Especially the country of asylum is held accountable, with criticism on the restrictions on refugee movement and employment possibilities, the confinement to camps and the lack of long-term perspectives and planning (UNHCR, 2005: 15I). In the case of Tanzania, such a view is disputable. The increasingly restrictive refugee policy of Tanzania, whose 'Open Door' policy has led to the Nansen Award in I983 (Kamanga, 2005: 100), will further be argued to be rather an unavoidable and understandable evolution. Indeed, it seems unreasonable to expect from a developing country, that has its own economic difficulties, not only to host a huge number of refugees but also to provide local integration as a durable solution, when the community of developed countries shows reluctance towards burden-sharing through resettlement or financial assistance. 


\section{Durable solutions in Tanzania: the lack of international burden-sharing}

Although the Preamble to the I95I Convention recognises the 'need' for international cooperation in order to achieve durable solutions, the reality is that neither general international law nor treaty obliges States to agree on or to offer durable solutions (Goodwin-Gill \& McAdam, 2007: 489). One can wonder why this is still the case? Some consider such a development undesirable. These opposers argue that it would relieve the country of origin of its responsibility to establish the conditions permitting return (Goodwin-Gill \& McAdam, 2007: 489). Although this would seem to be a valid reasoning, it is often revealed in practice that it is not the country of origin but the neighbouring developing countries that are bearing the burden of refugees and are expected to search for solutions. Thus, this paper does not support the above-mentioned idea of undesirability, but would rather attribute the lack of international commitment to durable solutions to the UNHCR's, the media's and so also the donor governments' preference for emergency refugee situations (UNHCR, 2006: II4; Crisp, 2003: 9) and to the post-Cold War States mentality, where northern countries in the era of globalization see no reason to share the burden of the poor South (Chimni, 1999: 17). Through exclusionary or deterrent policies and their geographical and cultural distance from regions of refugee origin, rich countries have avoided responsibility (UNHCR, 2006: I46). Thus, the lack of an international legal framework that would foster durable solutions creates inaction on the part of the developed countries, that thus turn their back on suffering host countries, which after all, just as the developed countries, generally had no part in the conflict or persecution leading to the displacement situation.

The lack of international burden-sharing is also apparent in the evolution over time of the 'most preferable durable solution' according to (the dominant states of) the international community. While, generally speaking, from 1945 until 1985 , the resettlement solution was promoted in practice, from the mid-r980s onwards voluntary repatriation was considered as the durable solution, followed by the doctrine of safe return in 1993 and the notion of imposed return in I996 (Chimni, I999: I; Crisp, 2003: 3). Why was repatriation 'suddenly' considered as the only viable durable solution? Unlike during the Cold War period, northern states no longer had any interest in the resettlement of refugees as labour forces (Chimni, 1999: 2 and 4). State interests have triumphed over responsibility and solidarity: ... international refugee policy ... is principally articulated by the developed countries to contain and manage the global refugee problem in the light of their interests (Chimni, 1993: 443). Consequently, political failures, neglect and unequal distribution of resources result in protracted refugee situations (UNHCR, 2005: 158). In this context, and taking into account the presence of economic difficulties that Tanzania has been facing, it is not surprising that, as will be seen below, Tanzania's refugee law and practice have become increasingly severe in the course of time. 


\section{The spiral of Tanzania's refugee policy}

Evolution from 'Open Door' to Refugees Act 1998

Tanzania tops the list of refugee-hosting countries in Africa, and is well-known for its historic generosity towards refugees (Mendel, I997: 35; Kamanga, 2005: I0I). In I959, the first wave of asylum seekers arrived from Rwanda. Unlike what happened in most countries in the region, Tanzania's nationals have never been compelled to flee en masse as refugees. Reasons for Tanzania's attractiveness as a host country can be found in the 'porosity' of its borders, the country's culture of hospitality and humanitarianism and Tanzania's 'Open Door' policy, as well as the presence of fallow land, the political and socio-economic stability and tranquillity of the country, its cultural affinity with other African nations and the common ancestry (Kamanga, 2005: I01-I02). Tanzania's Open Door policy, expressed in the Refugees (Control) Act 1965, was pursued until 1998 and was characterised by group (as opposed to individual) determination of status, general allocation of land, local integration and the en masse offer of citizenship through naturalization (Kamanga, 2005: 103). In 1979, for example, Tanzania offered citizenship to 36,000 Rwandan refugees (Mendel, 1997: 43). However, the Refugees (Control) Act I965 also had a number of problematic characteristics, e.g. the very restricted rights of refugees (Mendel, 1997; Peter, 1997).

In 1998 , a sea change occurred towards the issue of refugees. The Refugees Act 1998 was adopted to bring existing legislation ... in conformity with the country's new obligations under the 1969 OAU Convention, to signal disengagement from the Open Door policy, to convey to the international community disenchantment with the humanitarian assistance system for being insufficiently responsive to the impact of refugees on economically impoverished ... Tanzania, and to assure the populace that [the] government is determined to address the problem (Kamanga, 2005: I04). With regard to the latter element, the refugees' presence was said to be a cause of insecurity, environmental degradation and unemployment (Kamanga, 2005: 104). Even though numerous genuinely positive provisions can be found in the Act, its deficiencies are indisputable (Kamanga, 2005: II4). It would be right to say that the I998 Act, compared to the previous $1_{96}$ Act, contains less 'quantity' and more 'quality'.

Whereas refugees in Nyerere-Tanzania (I964-I985) were seen as an economic asset, in Post-Nyerere-Tanzania they were considered as a threat to national security (see Van Hoyweghen, 200I).

Under the Refugees Act 1998 (section 4 (I) (a) (b) and (c)) three categories of individuals are considered as refugees: those who meet the criteria of the 195I Convention, i.e. persecution-related refugees; those who fit the expanded refugee definition in the I969 OAU Convention, i.e. mainly conflict-related refugees and possibly environmentrelated refugees; and finally those who belong to a group of persons which by notice in the Government Gazette has been declared to be refugees. A National Eligibility Committee considers the applications for refugee status and makes recommendations to the Minister who is responsible for refugee matters for grant or denial of refugee status and asylum (section 6 and 7 (a)). Under the Refugees (Control) Act 1965 , by comparison, no such a Committee existed neither was the recognition of refugee status partially based on established 
international or national criteria; the Minister responsible for refugees merely declared any class of persons to be refugees by order published in the Gazette (Refugees (Control) Act 1965 , section 3 (I) (a)).

\section{The dropping of 'local integration' as durable solution: blaming Tanzania?}

The evolution of Tanzania's refugee policy regarding durable solutions can be depicted as a spiral. Starting with the observation that most refugees are located in developing countries which have their own needs (in emergency one flees to the closest safe haven), in the long term those same host countries often bear the burden - for no international agreements exist on the express rights of refugees to durable solutions. Here, one should consider the various negative impacts refugee presence has for the host countries. For Tanzania, all this resulted, first, in a dramatic switch to a clear 'No More Refugees' policy: in March 1995, the Tanzanian government closed its border with Burundi to prevent any further refugee influx (Rutinwa, I996 (b): 295). This decision has been correctly characterized as being unfortunate but understandable (Rutinwa, 1996 (b): 300). Secondly, in December 1996, the Tanzanian government declared that all Rwandese refugees in Tanzania were expected to return home by the end of the year (Amnesty International, 1997: 2). This announcement of the government is said to have been endorsed and co-signed by the UNHCR (Amnesty International, I997: 2; see also Whitaker, 2002). Patience seemed to have run out and the doctrine of imposed return arose.

Lastly, change of practice leads to change in law: the Refugees Act 1998 does not refer explicitly any more to local integration or naturalization as a viable durable solution, but has confined itself to acknowledging only repatriation and resettlement (Kamanga, 2005: 108).

As such, protracted refugee situations continue to exist: since many conflicts drag on, repatriation is often impossible. Combined with the lack of local integration and resettlement policies, there seems to be no way out - literally nor metaphorically. To this can be added the declining donor support for long-standing refugee populations - donors lose interest because of a lack of solutions (Goetz, 2003:4) - and a complaining, dissatisfied populace (UNHCR, 2006: II4; Goetz, 2003: 4). And the spiral continues turning. Tanzania, however, is not the party that is responsible for the plight of those refugees who are finding themselves in protracted refugee situations in Tanzania.

\section{Conclusion}

International action and cooperation are required to stop the spiral of national policy restrictions towards the issue of refugees in Tanzania, as well as in every other country affected by protracted refugee situations. Over the past years, new (multilateral) approaches and ideas regarding durable solutions have been developed (see e.g. Rutinwa, I996 (a): 312), under the guidance of the UNHCR. Concepts such as 'Development Assistance to Refugees', 'Development Through Local Integration', the '4Rs', 'Group Methodology' and the strategic use of resettlement emphasize the links between refugee aid, durable solutions, development and security, and thus the need for an in- 
tegrated approach (UNHCR, 2003; Goodwin-Gill \& McAdam, 2007: 500-505; UNHCR, 2006: I20-I27 and I46-I5I; UNHCR, 2005: 155). Hathaway and Neve (I997: 21I) advocate a 'common but differentiated responsibility' ... calling on states to contribute in ways that correspond to their relative capacities and strengths. Indeed, some states may have capabilities for providing physical protection, while others could provide financial resources. However, to make it all work in practice one ingredient is indispensable: political will.

What is the future for Tanzania? Clearing the country of the accusation of being immoral in restricting its refugee policy does not mean that Tanzania is free from responsibility. Where local integration through naturalization does not appear to be a viable solution - during the past decade Tanzania granted citizenship to a mere 730 refugees (UNHCR, 2008: II) - ... self-reliance and local settlement should be vigorously pursued as an interim measure (Crisp, 2004: 7; Crisp, 2003: I4I-I44); rather than confinement to camps. Because after all, long-term, costly and complicated care-and-maintenance programmes bring few lasting benefits to host countries, donor states or to refugees themselves. Enabling refugees to make a contribution to the economy of the host country makes their presence $a$ boon rather than a burden to the local population (Crisp, 2004: 7; Crisp, 2003: I4I). Also, once the causes of the flight have disappeared, local settlement and self-reliance do not preclude the possibility of voluntary repatriation, or as Crisp (2004: 8) writes: ... refugees who enjoy a high degree of legal, economic and social security in their country of asylum are better equipped for the task of return and reintegration than those who have been warehoused in camps for many years on end. The resources required to promote this strategy can thus be regarded as an investment in both local development and in regional peace-building. Indeed, ... regardless of the protracted situation's final solution, i.e. repatriation, resettlement, or local integration, participants in such [self-reliance] programs will have a smoother transition into their new lives (Goetz, 2003: 45).

The recommendation to Tanzania to follow this approach can be linked with the following reasoning of Hathaway (2006: 4 and 2I), namely that ... refugee law exists precisely in order to ensure that refugees enjoy true dignity and quality of life for as long as it takes them to decide for themselves how best to cope, to respond and to rebuild their lives. Policy priority, he concludes, should be given to 'refugee solutions' over 'solutions to refugeehood': it is not primarily about looking for solutions, but about ensuring autonomy and thus, respect for refugee rights.

\section{References}

Amnesty International (1997). Great Lakes Region: Still in Need of Protection: Repatriation, Refoulement and the Safety of Refugees and the Internally Displaced. Doc. No. AFR/02/07/97.

Centre For the Study of Forced Migration (CSFM) (2003). The Impact of the Presence of Refugees in Northwestern Tanzania. University of Dar Es Salaam.

Chimni, B. (1993). The Meaning of Words and the Role of UNHCR in Voluntary Repatriation. International Journal of Refugee Law, 5(3): 442-460.

- (1999). From Resettlement to Involuntary Repatriation: Towards a Critical History of Durable Solutions to Refugee Problems. New Issues in Refugee Research: Working Paper No. 2 (UNHCR).

Crisp, J. (2003). No Solution in Sight: The Problem of Protracted Refugee Situations in Africa. New Issues in Refugee Research: Working Paper No. 75 (UNHCR). 
- (2004). The Local Integration and Local Settlement of Refugees: $a$ Conceptual and Historical Analysis. New Issues in Refugee Research: Working Paper No. 102 (UNHCR).

Goetz, N. (2003). Lessons From a Protracted Refugee Situation. The Centre for Comparative Immigration Studies, Working Paper No. 74.

Goodwin-Gill, G. \& McAdam, J. (2007). The Refugee in International Law. Oxford: Oxford University Press, $600 \mathrm{p}$.

Hathaway, J. (1997). The Meaning of Repatriation. International Journal of Refugee Law, 9: 55I-558.

Hathaway, J. \& Neve, R. (1997). Making International Refugee Law Relevant Again: a Proposal for Collectivized and Solution-Oriented Protection. Harvard Human Rights Journal, 10: 115-211.

- (2005). The Right of States to Repatriate Former Refugees. Ohio State Journal on Dispute Resolution, 20: pp. 175-216.

- (2006). Refugee Solutions or Solutions to Refugeehood? Lecture text delivered in London, October 2006, available at http://www.heythrop.ac.uk/images/stories/hirepl/events/2006_jrs_london_lecture.pdf. (last consulted on 25 February 2009).

Kamanga, K., (2005). The (Tanzania) Refugees Act of 1998: Some Legal and Policy Implications. Journal of Refugee Studies, I8(I): 100-Ir6.

Mendel, T. (1997). Refugee Law and Practice in Tanzania. International Journal of Refugee Law, 9(1): 35-59.

Peter, C. (1997). Rights and Duties of Refugees under Municipal Law in Tanzania: Examining a Proposed New Legislation. Journal of African Law, 4I(I): 8I-99.

Rutinwa, B. (1996) (a). Beyond Durable Solutions: an Appraisal of the New Proposals for Prevention and Solution of the Refugee Crisis in the Great Lakes Region. Journal of Refugee Studies, 9(3): 312-325.

- (1996) (b). Tanzanian Government's Response to the Rwanda Emergency. Journal of Refugee Studies, 9(3): 291-302.

UNHCR, (2003). Framework for Durable Solutions for Refugees and Persons of Concern (UNHCR).

_ Executive Committee of the High Commissioner's Programme, (2005). Protracted Refugee Situations. Refugee Survey Quarterly, 24: pp. 150-161.

(2006). The State of the World's Refugees: Human Displacement in the New Millennium. Oxford: Oxford University Press, $340 \mathrm{p}$.

- (2008). 2007 Global Trends: Refugees, Asylum-seekers, Internally Displaced and Stateless Persons. Geneva: UNHCR.

Van Hoyweghen, S. (200I). Mobility, Territoriality and Sovereignty in Post-Colonial Tanzania. New Issues in Refugee Research: Working Paper No. 49 (UNHCR).

Whitaker, B. (2002). Changing Priorities in Refugee Protection: the Rwandan Repatriation from Tanzania. New Issues in Refugee Research: Working Paper No. 53 (UNHCR).

\section{Legal Instruments}

The Convention relating to the Status of Refugees of 28 July 195I, I89 UNTS 137.

The OAU Convention Governing the Specific Aspects of Refugee Problems in Africa of ro September 1969, 100I UNTS 45.

Refugees Act, I998 [United Republic of Tanzania]. 9. I5 April 1999, available online in UNHCR Refworld at: http://www.unhcr.org/refworld/docid/3ae6b5obf.html (last consulted on 22 January 2009).

Refugees (Control) Act, $1_{965}$ [United Republic of Tanzania]. 2. 7 January 1966, available online in UNHCR Refworld at: http://www.unhcr.org/refworld/docid/3ae6b5294.html (last consulted on 22 January 2009). 